\title{
Anti-Rubella IgM status in antenatal checkup visiting women
}

\author{
KC KP, ${ }^{1}$ Malla S, ${ }^{1}$ Ghimire $P,{ }^{2}$ Khanal SP, ${ }^{1}$ Dumre SP ${ }^{1}$ \\ ${ }^{1}$ National Public Health Laboratory, Teku, Kathmandu, ${ }^{2}$ Central Department of Microbiology, Tribhuvan University, \\ Kathmandu, Nepal.
}

\section{ABSTRACT}

Background: Rubella is a viral infection. Congenital rubella syndrome is the most serious consequences of rubella which has been observed in pregnant women. This study has been done to reveal the association of rubella infection in women.

Methods: The serum specimens were collected from women during their regular antenatal check up, in, was included in the study. Specimens were tested at NPHL every week following standard operating protocol of NPHL utilizing Human ELISA (German) kits and reagents. The results of the tests along with the clinical histories collected from the patient on a proforma file carried by the patients were analyzed following standard statistical tools.

Results: During the three years study period, 320 serum samples were collected in 2006, 372 in 2007 and 400 in 2008, out of which 38 (11.87\%), 72 (19.35\%) and 49 (12.25\%) of the women visiting NPHL during their antenatal checkup were found positive to anti-rubella IgM antibody respectively, indicating recent infection. Almost above $80 \%$ of the positive cases were from age group 20-30 years.

Conclusions: The study showed the significant association of recent rubella infection in women which emphasizes requirement of adolescent or adult immunization with rubella vaccine at the earliest.

Key words: anti-rubella IgM, congenital rubella syndrome, pregnant women, rubella.

\section{INTRODUCTION}

Rubella is caused by Rubella virus; an enveloped, nonsegmented, positive sense RNA virus, which was first isolated in cell culture in 1962 by Perkman and Weller. ${ }^{1,2}$ It is a non-arthropod borne Toga virus which is the only member of the genus Rubi virus. ${ }^{3}$

Rubella usually with minor complications when contracted by pregnant women during the first trimester of pregnancy, can lead to miscarriage, stillbirth, or an infant born with congenital rubella syndrome (CRS). ${ }^{4,5}$ Some defects associated with CRS may be recognizable at birth, while others are detected months or even years later. ${ }^{6,7}$ The consequences of rubella infection in pregnant women is disastrous, so this study aims to find out the significance of rubella infection in women visiting NPHL for antenatal checkup.

\section{METHODS}

This is a cross sectional descriptive study based at National Public Health Laboratory (NPHL), Teku, Kathmandu from January 2006 to December 2008. The ethical approval and patient consent has been taken prior the sample collection. A total of 1092 blood samples during the three years study period, were collected from women of age 15 to 45 years, referred by the respective 
gynecologists for testing anti-rubella IgM antibodies at NPHL. All the serum samples collected from the women of age group from 15 years to 45 years were included in the study. Samples from the women above 45 years and below 15 years were not included in the study. All the blood samples were collected following standard methodology at NPHL and separated for serum for serodiagnostics. Thus obtained serum samples were stored at $-20^{\circ} \mathrm{C}$, after proper labeling, till further processing. The samples collected during the entire study period were tested on weekly basis using standard operating protocol developed at NPHL utilizing Human anti rubella IgM ELISA kit (Germany). ${ }^{8}$ The data was entered in the Microsoft excel spread-sheet 2003 and further analyzed by statistical tool (Chi square test), using WinPepi (Version 1.55 and 1.69; 2003-2007) as a statistical package software .

\section{RESULTS}

A total of 1092 serum samples from women of age group 15 to 45 years were collected during the entire period with 320 during 2006, 372 during 2007 and 400 during 2008.

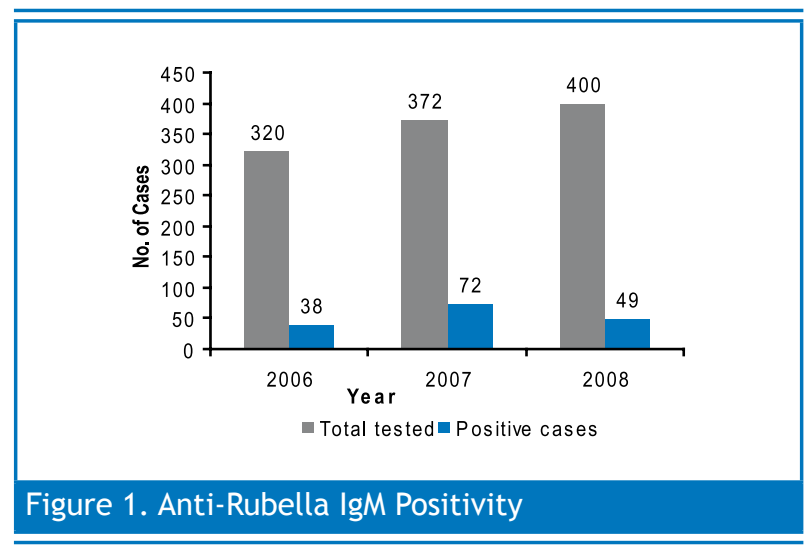

In the year 2006, of the total 320 serum specimens tested, $11.87 \%$ showed positive for anti-rubella IgM antibodies, likewise $19.35 \%$ were positive from 372 tested specimens during 2007 and $12.25 \%$ from 400 specimens tested during 2008.

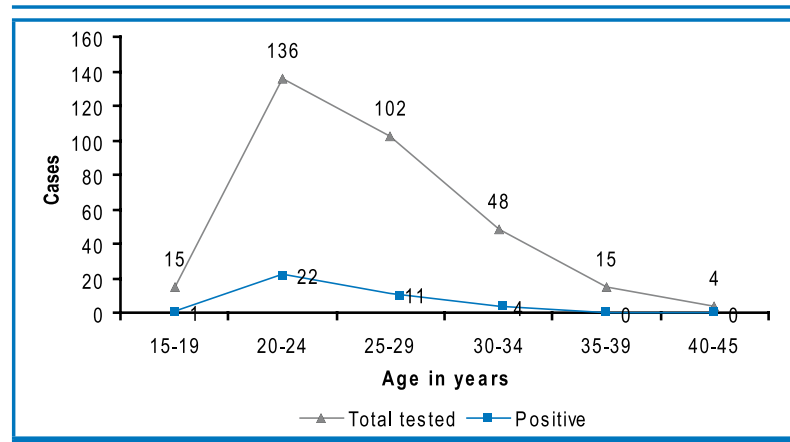

Figure 2. Age wise distribution of rubella in 2006
The age wise distribution of rubella in 2006 showed that the highest number of suspected cases and the positive cases were in the age group of 20 to 24 years with no positive cases above 35 years.

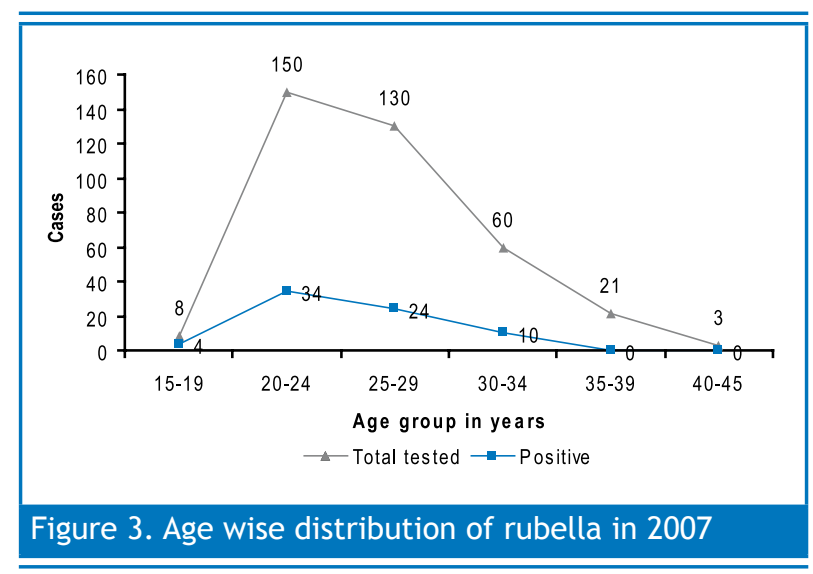

In 2007 also the highest number of rubella cases was from 20-24 year age group with no positive cases above 35 years.

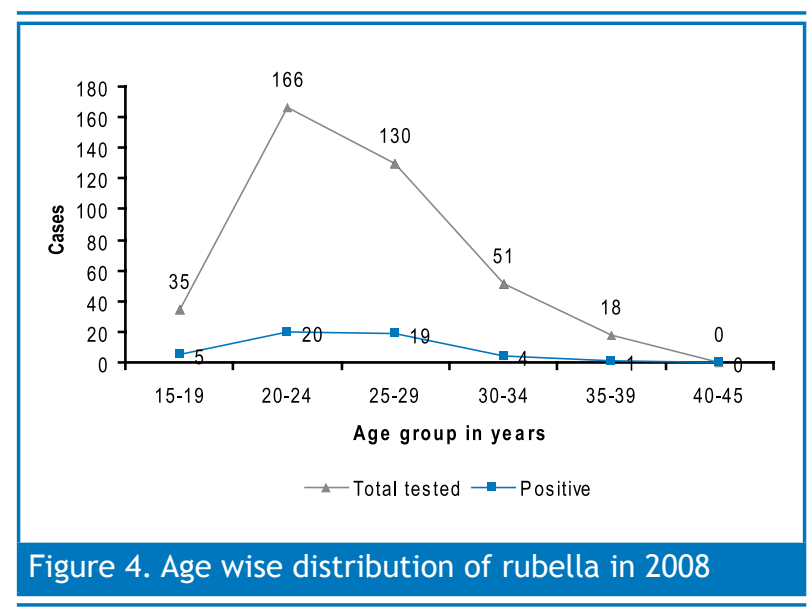

Here in age group 20 to 24 and 25 to 29 , rubella cases were comparable with no cases observed above 40 years.

\section{DISCUSSION}

This study was focused to reveal the incidence of rubella in women of child bearing age visiting NPHL for antenatal checkup by detecting anti-rubella IgM antibodies in serum samples which indicates the recent infection, in contrast to anti-rubella IgG antibodies which gives life long immunity. In developing countries, rubella outbreaks can occur with out clinical recognition thus the prevalence of rubella can not be assessed with out the serological evidence. , $^{910}$ The present findings will be helpful for the commencement preventive measures against rubella and CRS as in context of selection and formulating the target population for MMR vaccination 
as the recognition of CRS is often hindered by its subtle or delayed manifestations, which contributes to the lack of data on the incidence of CRS. ${ }^{11}$

Worldwide, it is estimated by WHO those more than 100,000 infants are born with congenital rubella syndrome annually. ${ }^{5}$ The annual WHO report showed that cases have been increasing in recent years with more disease burden in developing countries where rubella vaccination have not been introduced. ${ }^{12,13}$ Studies demonstrated that in many developing countries rubella infects children at different ages and that varying proportions of women have not acquired the protective antibody when they reach the child bearing age. ${ }^{14-16}$ The highest risk for the CRS is found in the countries with high susceptibility rate among the women of child bearing age. Understanding of the epidemiology of Rubella in Asian countries is relatively limited, because there are many other prioritized childhood diseases. ${ }^{17}$ Serosurveys from 45 developing countries have shown a wide range of susceptibility: the proportion of rubella sero-negative women was $25 \%$ or higher in 12 countries, $10 \%-24 \%$ in 20 countries, and below $10 \%$ in 13 countries ${ }^{18}$ but it seems possible that in underdeveloped countries like Nepal with no rubella immunization may have high incidence rate than do the reporting countries. To the best of our knowledge, based on reports and literature review, nation wide sero surveillance had not been conducted in the country till 2008.

During this study period $11.87 \%$ in $2006,19.35 \%$ in 2007 and $12.25 \%$ in 2008 , of the women's during different age, tested positive for anti rubella IgM antibody. These were mostly women who visited maternity hospital (Paropakar Maternity and Women's Hospital) Katmandu for their regular antenatal check ups and are referred to NPHL However; this maternity hospital is a major hospital of the country where women throughout the country visit for check ups and majority of the patients it caters come from low middle class family living in and around Katmandu valley. Although the result may not represent whole country on epidemiological and geographical grounds, Katmandu valley being a cosmopolitan city roughly represents the indication of rubella infection during pregnancy in Nepal.

The unpublished data of NPHL also showed the antirubella positivity of $8.55 \%, 6.82 \%, 12.8 \%$ and $14.7 \%$ during 2001/2, 2002/3, 2003/4 and2004/5 respectively. This indicates recent rubella infection.

In 2006, it was observed that the highest no of positive cases (22 cases) were in 20-25 years which constitutes $57.89 \%$ of the total positive cases, 11 cases in 25-30 years which accounts for $28.95 \%$ of the total positive cases, 4 cases $(10.53 \%)$ in $30-35$ years and a case in $15-20$ years of age. The sero-positive trend in 2007 and 2008 is more or less similar to 2006 where of the total positive cases were clustered with in the age group of 20-30 years which comprised almost $80 \%$ of the total positive cases in each year. No positive case above 35 years in 2006 and 2007, however single case is observed in 2008. Though the association between age group and rubella infection is not found statistically significant for 2006 and 2008 $\left(P=0.302, x^{2}=6.045\right.$ for 2006; $P=0.035, x^{2}=11.972$ for 2007 and $P=0.646, x^{2}=2.49$ for 2008).

The higher percentage of positive cases and the total tested cases in the age groups 20-30 years may be because many of the women's marry in their early 20's and get pregnant during the same period in context of our social practices. However, the low sample size in age group 15-20 might be due to the women getting married after 20 years and all the samples of child bearing aged women were received as a part of ante-natal checkup. Such pattern of distribution of rubella positive cases might be due to the natural immunity acquired by the rubella infection in early age of life as there is no policy for immunization against the rubella virus infection in the country. This is why the positive cases were in decreasing pattern as with the increase in age groups.

\section{CONCLUSIONS}

The present findings indicates $20-30$ years age group as more vulnerable age group for Rubella infection which might as a consequence can lead for the public health burden because this is the most common child bearing age group in context of our country. Thus, this study result stresses need for more extensive studies on the Rubella seroprevalence with different age groups and geography to give more information.

\section{ACKNOWLEDGEMENTS}

The authors would like to acknowledge the staff of NPHL.

\section{REFRENCES}

1. Katow S, Minahara H, Fukushima M , Yamaguchi Y. Molecular epidemiology of rubella by nucleotide sequence of the Rubella Virus $\mathrm{E}_{1}$ gene in three east asian countries. J Infect. Dis. 1997; 176(3):602-16.

2. Frey TK. Molecular biology of Rubella Virus. Adv Virus Res. 1994;44:69-160.

3. Ananthanarayan R, Panikar CKJ. Textbook of Microbiology. 6th ed. India: Orient Longman Ltd; 2000. p. 522-25.

4. Banatvala JE, Best JM. Rubella. In: Collier L, Balows A, Sussman M, editors. Topley and Wilson's Microbiology and Microbial infections. 9th ed. London: Arnold; 1998. p. 551-72. 
5. Robertson SE, Featherstone DA, Gacic-Dobo M, Hersh BS. Rubella and congenital rubella syndrome: global update. Rev Panam Salud Publica. 2003 Nov; 14(5): 306-15. .

6. Robertson SE, Cutts FT, Samuel R, Diaz-ortega JL. Control of rubella and congenital rubella syndrome (CRS) in developing countries, part II: vaccinations against rubella. Bull World Health organ. 1997;75:69-80.

7. Mellinger AK, Cragan JD, Atkinson WL. High incidence of congenital rubella syndrome after rubella outbreak. Pediatr Infect Dis J. 1995 Jul;14(7):573-78.

8. Human Biochemical and Diagnostics. ELISA Test for the Detection of IgM Antibodies to Rubella Virus in Human serum. German Kit: Leaflet Insert. 2006.

9. Vijaylakshmi P, Anuradha R, Prakash K, Narendran K, Ravindran M, Prajna L, et al. Rubella serosurveys at three Arvind Eye hospitals in Tamil Nadu, India. Bull World Health Organ. 2004 Apr;82(4):259-64.

10. Benenson AS, editor. Control of communicable disease manual. 16th ed. Washington DC: American Public Health Association; 1995.

11. Joan LR, Bonita EL, Jutta KP, Sabrina P, Graham AT. Prevention of congenital Rubella syndrome - what makes sense in 2006? Epidemiol Rev. 2006;28:81-7.
12. World Health Organization. Rubella reported cases. Geneva: WHO; 2006 Dec.

13. World Health Organization. Manual for the laboratory diagnosis of measles and rubella virus infection. 2nd ed. Vol 2. New Delhi: WHO SEARO; 2006. p. 11-23.

14. Kanbur NO, Derman O, Kutluk T, Kinik E. Age specific rubella seroprevalence of an invaccinated population of adolescents in Ankara, Turkey. Jpn J Infect Dis. 2003;56:23-5.

15. Miller C. Rubella in the developing world. Epidemiol Infect. 1991;107:63-8.

16. World Health Organization. Guidelines for surveillance of congenital rubella syndrome and rubella: field version. Geneva : Department of Vaccines and Biologicals, WHO; 1999 May.

17. Katow S. Molecular epidemiology of Rubella virus in Asia: utility for reduction in the burden of disease due to congenital rubella syndrome. Pediat Int. 2004 Apr;46(2):207-16.

18. Cutts FT, Robertson SE, Diaz-Ortega JL, Samuel R. Control of rubella and congenital rubella syndrome (CRS) in developing countries, part 1: burden of disease from CRS. Bull World Health Organ. 1997;75:55-68. 